\title{
Is functional skills mathematics approach relevant to stimulate students' mathematical problem solving?
}

\author{
R Oktaviyanthi* ${ }^{1}$, R N Agus ${ }^{2}$, Y Supriani ${ }^{3}$ and U Sholahudin ${ }^{4}$ \\ ${ }^{1,2,3,4}$ Universitas Serang Raya, Jl. Raya Serang Cilegon Km. 5, Taman Drangong, \\ Serang, Banten
}

rinaokta1210@yahoo.com

\begin{abstract}
This study described the stimulation structure of problem-solving skills obtained by students who were taught mathematics using functional skills mathematics approach. A descriptive exploratory qualitative approach was used to examine the students' stimulation structure. Participants included three students from different level of mathematics ability in the second semester students of mathematics education program at Universitas Serang Raya. The data gained from the students' problem-solving working collaborated with in-depth interviews focused on the students' thinking refers to the functional skills mathematics completeness indicator. Exploration results showed the percentage of stimulation for each student of high, moderate and low mathematics ability are $81.8 \%, 54.5 \%$ and $36.7 \%$. The relevance of the implementation of the functional skills mathematics approach was explained in more detail in the discussion.
\end{abstract}

\section{Introduction}

Problem solving is a cognitive aspect [1] concerned by researchers to continue developed in students time by time. Moreover, it is the main of the cognitive goal of education [2][3], including the tertiary level of education. In Indonesia, the problem-solving skills are contained in the competency standards of graduates and the demands of the Indonesian National Qualifications Framework (KKNI) of the bachelor graduates at level 6 [4].

The research focused on problem-solving skills has been accomplished in the various way, especially by the authors, for instance in the internal factors supported the problem-solving skills [5], the external factors contributed the improvement problem-solving skills, employing the ICT of learning to increase the students' mathematical performance [6], implementing the learning models supported the problem-solving skills [7], applying the students' guided worksheets [8], and the latest research is the implementation of functional skills mathematics approach completed by the authors [9]. The conclusion of the study stated the students' problem-solving skills tended to increase by the students who taught mathematics using functional skills mathematics approach.

Evaluating the effectiveness of the implementation of functional skills mathematics approach within a certain period of time is an important procedure to reach a quality of teaching and learning management, for example the exploration of the students' devising strategies skills. The evaluation is a series of the procedures in shaping the quality of teaching and learning management in the classroom between teachers and students [10][11][12]. The presentation of students' work is a general description that can be used as a clue about the effectiveness of learning [13][14]. Thus the purpose of 
this study is to describe the stimulation structures of problem-solving skills achieved by students who were taught mathematics using functional skills mathematics approach. There are two advantages of exploring the students' work are to obtain the students' problem-solving skills reflection at various levels of the students' academic ability and to become a recommendations in the implementation of further learning activities.

\section{Methods}

To find out the stimulation structure of problem-solving skills accepted by students who received mathematics using functional skills mathematics approach, a descriptive exploratory qualitative approach was implemented. Three first-year students with different ability in mathematics who enrolled in the Calculus II courses in the department of mathematics education, Universitas Serang Raya were participated in research.

Tabel 2. The stages of FSM approach and the indicators of problem-solving skills

\begin{tabular}{|c|c|c|c|}
\hline \multirow{2}{*}{$\begin{array}{l}\text { The Stages of } \\
\text { FSM Approach }\end{array}$} & \multirow{2}{*}{$\begin{array}{l}\text { The Indicators } \\
\text { of Problem- } \\
\text { Solving Skills }\end{array}$} & \multicolumn{2}{|c|}{ The Descriptions of FSM Learning Approach } \\
\hline & & The Lectures Part & The Students Part \\
\hline Representation & $\begin{array}{l}\text { Choosing a } \\
\text { plan for } \\
\text { problem- } \\
\text { solving } \\
\text { strategies }\end{array}$ & $\begin{array}{l}\text { Providing the thinking } \\
\text { stimulation through } \\
\text { the logical and } \\
\text { reasonable } \\
\text { presentation of } \\
\text { mathematical } \\
\text { problems }\end{array}$ & $\begin{array}{l}\text { - (R1) Presenting the data or the } \\
\text { information from the given problem } \\
\text { situations in the form of diagrams, } \\
\text { graphs, tables or images } \\
\text { - (R2) Formulating the mathematical } \\
\text { equations or models based on the } \\
\text { problem situations which have been } \\
\text { transformed into other representations } \\
\text { - (R3) Deciding the use of problem- } \\
\text { solving methods appropriate to the } \\
\text { problem situation } \\
\text { - (R4) Inscribing the steps solution for } \\
\text { completion }\end{array}$ \\
\hline Analysis & $\begin{array}{l}\text { Solving the } \\
\text { problem }\end{array}$ & $\begin{array}{l}\text { Presenting the } \\
\text { examples of a problem } \\
\text { analysis process, } \\
\text { guiding in the } \\
\text { selection of problem- } \\
\text { solving strategies, } \\
\text { reducing the level of } \\
\text { assistance }\end{array}$ & $\begin{array}{l}\text { - (A1) Determining the appropriate } \\
\text { mathematical procedures } \\
\text { - (A2) Confirming the patterns and the } \\
\text { problems connection with the used of } \\
\text { problem-solving strategies } \\
\text { - (A3) Working on the problem-solving } \\
\text { until finding the results }\end{array}$ \\
\hline Interpretation & $\begin{array}{l}\text { Verifying and } \\
\text { interpreting } \\
\text { the results }\end{array}$ & $\begin{array}{l}\text { Directing to evaluate } \\
\text { the whole problem- } \\
\text { solving process, } \\
\text { giving the examples } \\
\text { and the sight in } \\
\text { drawing the exact } \\
\text { conclusions related to } \\
\text { the problem context }\end{array}$ & $\begin{array}{l}\text { - (I1) Re-examining the taken problem- } \\
\text { solving steps } \\
\text { - (I2) Explaining the problem-solving } \\
\text { results according to the context } \\
\text { - (I3) Drawing the conclusions from the } \\
\text { whole problem-solving process } \\
\text { - (I4) Interpreting the obtained problem- } \\
\text { solving results }\end{array}$ \\
\hline
\end{tabular}

The main instrument of the study was the researcher himself assisted by the written tests as supporting instruments. The two written test questions taken from Applied Derivatives subject have been validated and feasible to use to measure the mathematical problem-solving skills. The written test given at the different times to notice the students' consistency in answering questions. 
There are 11 indicators of problem-solving skills (Table 1) which have been categorized according to the stage of functional skills mathematics approach. For the purposes of this study, the mark of each of the indicator is 1 and the total $100 \%$ performance of achievement is 11 points.

The results of the written test confirmed through interviews and analyzed refer to the analysis techniques by Miles and Huberman [15]. The data validation verified using the triangulation technique [16].

\section{Results}

\section{Student's low-level mathematical ability (S1)}

The first written test of S1 confirmed by a second written test. The test results explained the similar work pattern and equivalent logical process, hence it can be said that the written test results of S1 were valid. The written test used as an analysis data reference for S1 was the first written test presented in Figure 1.

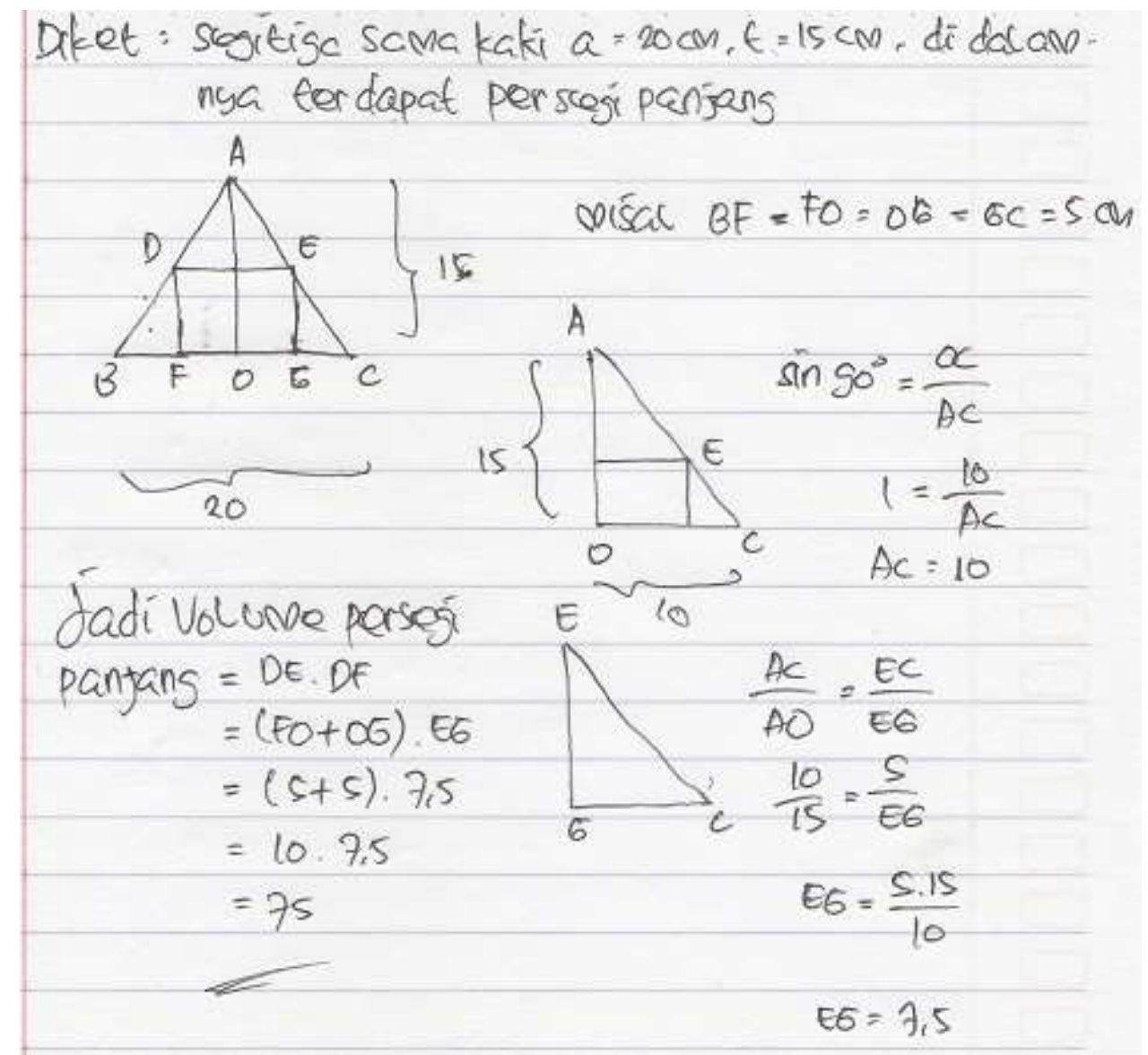

Figure 1. The written test results of S1

The S1 solved the problem by writing down the known information, followed by drawing visualization according to the information obtained. In the interview known, the aim procedure of S1 was to find the area of DEFG, thus the solution was to find the value of DE or FG and DF or EG. He drew an isosceles triangle ABC filled by a rectangle DEFG. Then divide the isosceles triangle into two equal parts, as a result the right triangle of ADC obtained. He used the concepts of trigonometry and congruence to find a rectangular volume in an isosceles triangle. He wrote 'volume', but confirmed, what meant was the area of DEFG. Overall, the S1 failed to lead onto way problem-solving meaning. The concept expected to rise was an applied derivatives, specifically the 
maximum rectangular area formed by an isosceles triangle with $20 \mathrm{~cm}$ in width and $15 \mathrm{~cm}$ in height.

From the results of the completion expressed by S1, it assessed $36.7 \%$ for the overall achievement of the problem-solving indicators. Table 2 is the details of the indicators achieved.

Tabel 2. The completion of problem-solving indicators achieved by S1

\begin{tabular}{lc}
\hline \multicolumn{1}{c}{ The Indicators of Problem-Solving Skills } & $\mathrm{S} 1$ \\
\hline - (R1) Presenting the data or the information from the given problem & $\mathrm{V}$ \\
situations in the form of diagrams, graphs, tables or images & \\
- (R2) Formulating the mathematical equations or models based on the & $\mathrm{V}$ \\
problem situations which have been transformed into other & - \\
representations & - \\
- (R3) Deciding the use of problem-solving methods appropriate to the & \\
problem situation & $\mathrm{V}$ \\
- (R4) Inscribing the steps solution for completion & - \\
- (A1) Determining the appropriate mathematical procedures & $\mathrm{V}$ \\
- (A2) Confirming the patterns and the problems connection with the used & - \\
- of problem-solving strategies & - \\
- (A3) Working on the problem-solving until finding the results & - \\
- (I2) Explaining the problem-solving results according to the context & - \\
- (I3) Drawing the conclusions from the whole problem-solving process & - \\
- (I4) Interpreting the obtained problem-solving results & $4 / 11=36.7$ \\
Total &
\end{tabular}

\section{Student's moderate-level mathematical ability (S2)}

By the similar technique, the written test used as an analysis data reference for S2 presented in Figure 2.

The S2 answered the problem by drawing the identified information and constructing the completion steps using the arrow symbol. In the interview recognized, finding the value of $\mathrm{x}$ as the width of the rectangle and the value of $y$ as the height of the rectangle were the purpose of problem solving accomplished by $\mathrm{S} 2$. He sketched an isosceles triangle $\mathrm{ABC}$ with the rectangle inside and the line $\mathrm{AD}$ as the height of the triangle which divides the two triangles congruently. Then the right triangle ADC with DEFG rectangle inside was earned. He employed the concept of plane figure area in finding $x$ and $y$ values. He constructed the formula of $\mathrm{y}$ and substituted it to the rectangle area $2 \mathrm{xy}$. He recognized the concept to be applied to solve the problem, that is the derivatives. In the interview known the recognizing process of S2 that the derivatives was the answer by the keyword 'maximum' of the question 'how much is the maximum rectangular area can be formed from an isosceles triangle with $20 \mathrm{~cm}$ in width and $15 \mathrm{~cm}$ in height?'. 


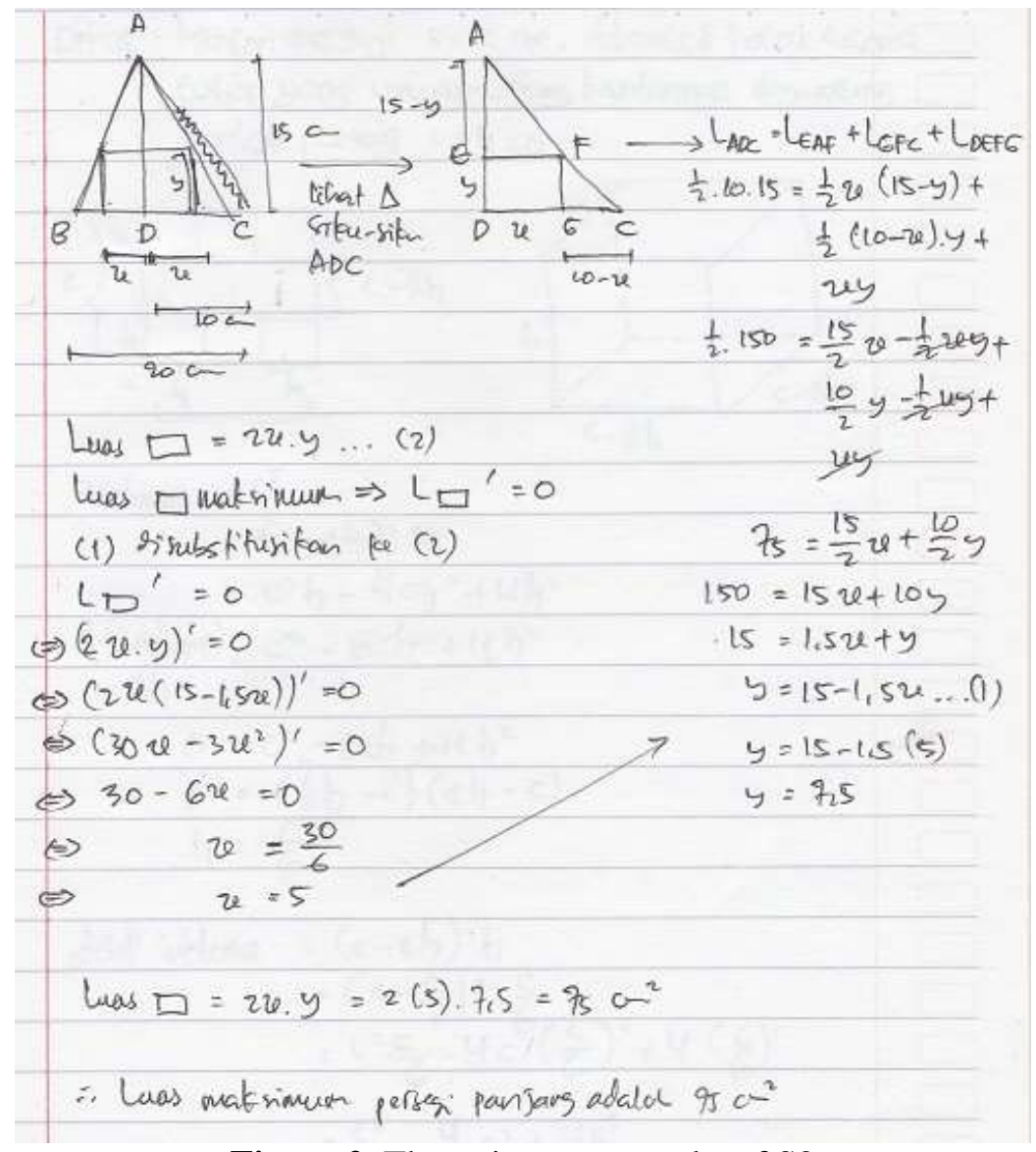

Figure 2. The written test results of S2

Overall achievement of the S2 in problem-solving indicators was quite good 54.5\%. The details of the S2 indicators achievement attached in Table 3.

Tabel 3. The completion of problem-solving indicators achieved by $\mathrm{S} 2$

\begin{tabular}{lc}
\hline \multicolumn{1}{c}{ The Indicators of Problem-Solving Skills } & $\mathrm{S} 1$ \\
\hline - (R1) Presenting the data or the information from the given problem & $\mathrm{V}$ \\
situations in the form of diagrams, graphs, tables or images & \\
- (R2) Formulating the mathematical equations or models based on the & $\mathrm{V}$ \\
problem situations which have been transformed into other & \\
representations & $\mathrm{V}$ \\
- (R3) Deciding the use of problem-solving methods appropriate to the & - \\
- problem situation & $\mathrm{V}$ \\
- (R4) Inscribing the steps solution for completion & - \\
- (A1) Determining the appropriate mathematical procedures & \\
- (A2) Confirming the patterns and the problems connection with the used & $\mathrm{V}$ \\
of problem-solving strategies & - \\
- (A3) Working on the problem-solving until finding the results & - \\
- (I1) Re-examining the taken problem-solving steps & $\mathrm{V}$ \\
- (I2) Explaining the problem-solving results according to the context & - \\
- (I3) Drawing the conclusions from the whole problem-solving process & (I4) Interpreting the obtained problem-solving results \\
Total & $6 / 11=54.5$ \\
\hline
\end{tabular}




\section{Student's high-level mathematical ability}

Through the comparable method, the written test used as an analysis data reference for S3 presented in Figure $3 a$ and Figure $3 b$.

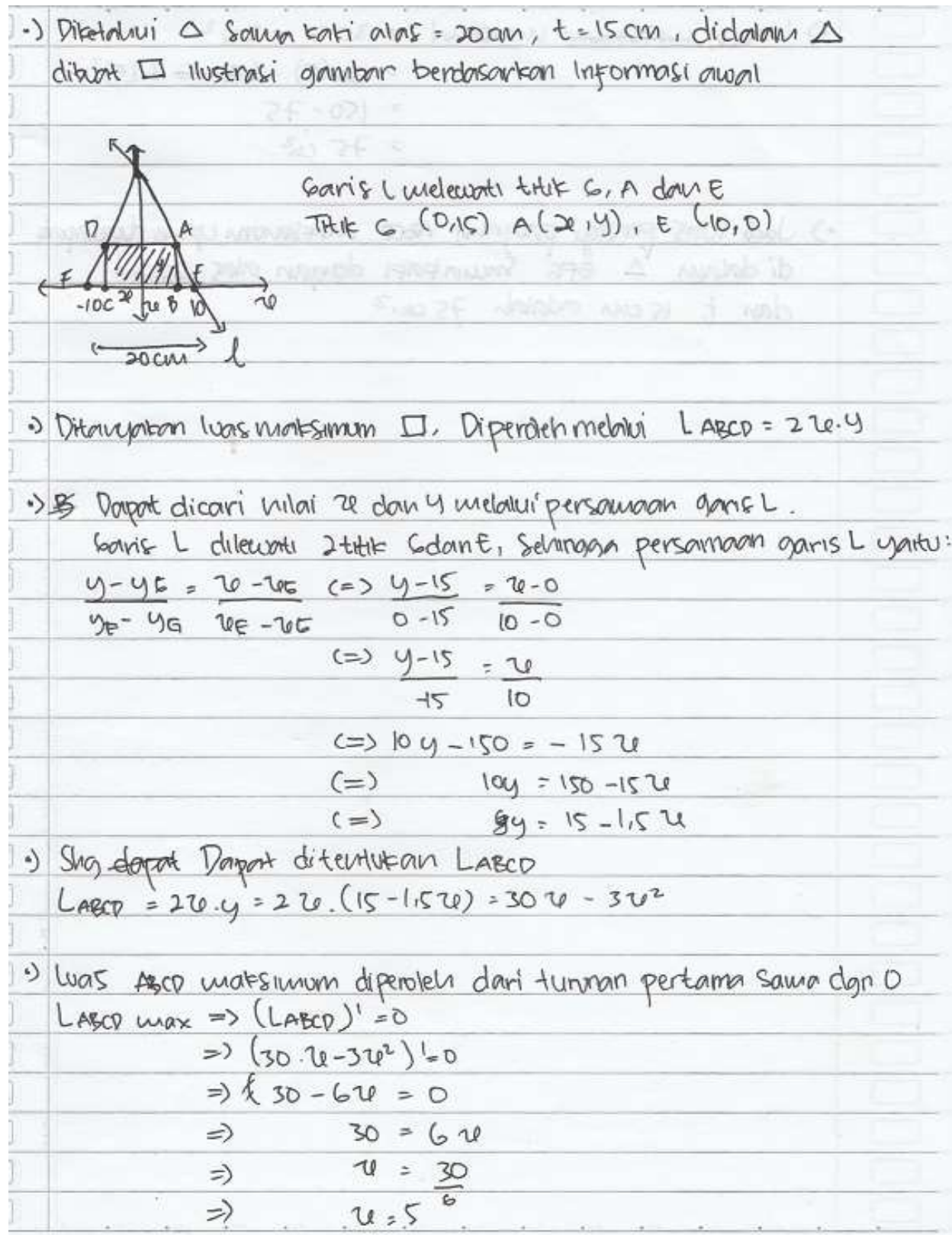

Figure 3a. The written test results of S3 


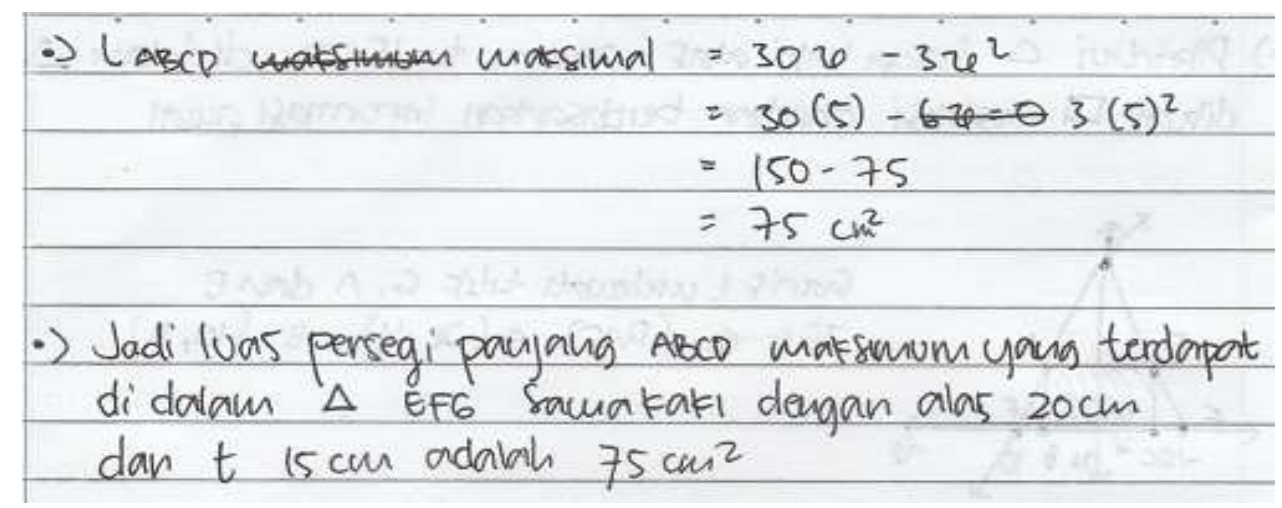

Figure 3b. The written test results of S3

The S3 clarified the problems with the understandable stages. He initiated the problem-solving by writing down what was known. Then He represented the information by drawing an isosceles triangle with the width of the triangle on the $x$ axis and the height of the triangle on the $y$ axis. In the confirmation made by the authors, the $\mathrm{S} 3$ approached the problem by using the concept of a line in the Cartesian coordinates. He noticed one of the side of the isosceles triangle as the line $l$ passes through the points G, A and E. He realized what asked was the maximum rectangle area and related to the derivative concept. He noted down the rectangle area with the symbol LABCD $=2 x y$. Then he investigated for the values of $x$ and $y$ through the equation of the line $l$. He found LABCD as the quadratic form in variable $\mathrm{x}$. The S3 said that to find the maximum area he have to apply the first derivative concept. In terms of completion concepts and procedures, S3 provided a good results.

The achievement completed by S3 is $81.87 \%$ for the overall problem-solving indicators. Table 4 is the details of the indicators achieved.

Tabel 4. The completion of problem-solving indicators achieved by S3

\begin{tabular}{ll}
\hline \multicolumn{1}{c}{ The Indicators of Problem-Solving Skills } & $\mathrm{S} 1$ \\
\hline - (R1) Presenting the data or the information from the given problem & $\mathrm{V}$ \\
situations in the form of diagrams, graphs, tables or images & \\
- (R2) Formulating the mathematical equations or models based on the & $\mathrm{V}$ \\
problem situations which have been transformed into other & \\
representations & \\
- (R3) Deciding the use of problem-solving methods appropriate to the & $\mathrm{V}$ \\
problem situation & - \\
- (R4) Inscribing the steps solution for completion & $\mathrm{V}$ \\
- (A1) Determining the appropriate mathematical procedures & - \\
- (A2) Confirming the patterns and the problems connection with the used & - \\
- of problem-solving strategies & $\mathrm{V}$ \\
- (A3) Working on the problem-solving until finding the results & $\mathrm{V}$ \\
- (I2) Exp-examining the taken problem-solving steps & $\mathrm{V}$ \\
- (I3) Drawing the problem-solving results according to the context & $\mathrm{V}$ \\
- (I4) Interpreting the obtained problem-solving results & $\mathrm{V}$ \\
Total & $9 / 11=81.8$ \\
\hline
\end{tabular}

\section{Conclusion}

Based on the problem-solving procedure completed by three students in different level mathematical ability after the learning process used the functional skills mathematics, the percentage of problem solving indicators achieved in each student were $36.7 \%, 54.5 \%$ and $81.8 \%$. These results provide an 
indication that the functional skills mathematics learning approach supported the completion of the work by S2 and S3. The results obtained by S1 become an evaluation in designing material for improvement and development of learning.

\section{Acknowledgements}

The authors would like to thanks and gives the highest appreciation to the Directorate of Research and Community Service, Ministry of Research, Technology and Higher Education (KEMENRISTEK DIKTI), Republic of Indonesia who has funded this study in Dosen Pemula research scheme.

\section{References}

[1] Neumann D and Lequerica A 2009 Cognitive Problems After Traumatic Brain Injury US University of Washington

[2] Jonassen D H 2010 Research Issues in Problem Solving The 11th International Conference on Education Research New Educational Paradigm for Learning and Instruction 29 September-1 October 2010

[3] Groves S 2012 Developing Mathematical Proficiency Journal of Science and Mathematics Education in Southeast Asia 35 (2) 119-145

[4] Dirjen Belmawa 2015 Paradigma Capaian Pembelajaran: Dokumen 005 Jakarta Ristekdikti (http://kkni-kemenristekdikti.org/asset/pdf/005-dokumen_capaian_pembelajaran.pdf)

[5] Oktaviyanthi R and Supriani Y 2014 A description of the student's problem solving ability based on personality The International Seminar on Education 2014 Universitas Sultan Ageng Tirtayasa (https://osf.io/f5qpz)

[6] Oktaviyanthi R and Supriani Y 2014 Educational Technology: Applying Microsoft Mathematics to Enrich Students' Mathematics Learning and Increase Motivation International Journal of Education and Research, 2 (7), 317-328 (http://www.ijern.com/journal/July-2014/26.pdf)

[7] Oktaviyanthi R 2015) Kajian Model Pembelajaran: Pendekatan Cognitive Apprenticeship Model Case Based Reasoning dalam Pembelajaran Matematika Seminar Nasional Matematika 2015 Universitas Katolik Parahyangan (https://osf.io/586ae/)

[8] Oktaviyanthi R and Dahlan A J 2018 Developing Guided Worksheet for Cognitive Apprenticeship Approach in Teaching Formal Definition of the Limit of a Function The $2^{\text {nd }}$ International Conference on Mathematics, Science, Education and Technology Universitas Negeri Padang (http://iopscience.iop.org/article/10.1088/1757-899X/335/1/012120)

[9] Oktaviyanthi R and Agus R N 2018 Peningkatan Kemampuan Pemecahan Masalah Mahasiswa Calon Guru Melalui Keterampilan Fungsional Matematis Beta: Jurnal Tadris Matematika, 11 (1) $1-19$

[10] OECD Organisation for Economic Co-operation and Development 2013 Teacher Evaluation: A Conceptual Framework and Examples of Country Practices US OECD Publishing

[11] Muskin J A 2017 Continuous Assessment for Improved Teaching and Learning: A Critical Review to Inform Policy and Practice Paris UNESCO

[12] Korpershoek H Harms T de Boer H van Kuijk M and Doolaard S 2014 Effective Classroom Management Strategies and Classroom Management Programs for Educational Practice Netherland University of Groningen

[13] Fry H Ketteridge S and Marshall S 2003 A Handbook for Teaching and Learning in Higher Education: Enhancing Academic Practice Third Edition New York Routledge Taylor \& Francis Group

[14] O’Neill G 2015 Curriculum Design in Higher Education: Theory to Practice Dublin UCD Teaching and Learning (http://www.ucd.ie/t4cms/UCDTLP0068.pdf)

[15] Miles M B and Huberman A M 1992 Analisis Data Kualitatif Buku Sumber Tentang Metodemetode Baru Jakarta Universitas Indonesia Press

[16] Liamputtong P Qualitative Research Methods, $4^{\text {th }}$ Edition Australia and New Zealand Oxford University Pres 
This paper has been presented in "Mathematics, Science, and Computer Science Education International Seminar 2018”, Universitas Pendidikan Indonesia(UPI), Bandung, West Java, Indonesia, October 27, 2018. 